\title{
Multilingual Place Names in Southern Africa
}

\author{
LUCie A. MÖLleR
}

Unit for Language Facilitation and Empowerment, University of the Free State, Bloemfontein, South Africa

Numerous place names in southern Africa reveal cultural and language contact between Bushmen (San), Khoikhoi, Bantu and European language speakers over many thousands of years. These toponyms reflect the diversity of languages that had an influence on words and common names used by local people speaking different languages. Many of these place names are complex and their origins and meanings can only be explained by tracing onymic (naming) formatives in components from cognate words appearing in other languages, often only by deciphering the phonological, orthographic and morphological adaptations that they underwent, or through translated names elucidating the meanings. The findings of this research provide insights into the inter-connected, multilingual context and show names as being verifiable evidence of onymic, lexemic and toponymic exchange. They indicate language elements that survived in names that are part of the toponymic heritage of the region.

KEYWORDS Bushman, Khoikhoi, paleo-onomastics, onymic formatives, toponyms, language contact, multilingualism, acculturation.

\section{Introduction and background}

In southern Africa the social, physical and language contact, as well as cultural exchange that occurred between the speakers of various indigenous languages spoken in the region, are revealed in many place names. Research has shown that elements of different languages operating as onymic formatives and semantic sources may be observed, from the oldest layers of Stone Age hunter-gatherer Bushman languages to Khoikhoi and Bantu, to one of the most recent, modern languages on the continent, Afrikaans. This comes into focus when analyzing toponyms that refer to topographical features and to the fauna and flora that served as naming motives for such features in the landscape. 


\section{Historical contact situations and acculturation}

The Bushmen (San) lived in southern to central Africa for millennia, long before the Khoikhoi and Bantu-speaking agro-pastoralist peoples arrived. This migration by the new-comers had a profound effect on the original inhabitants, i.e. the Middle and Late Stone-Age hunter-gatherers, they and their languages being either displaced and/or assimilated.

The acculturation of the Bushmen and their languages occurred in different phases and with an overlap of pre-historic to historic time, encompassing different contact experiences. The initial contact was with the Khoikhoi-speaking peoples, a neighboring group, genetically and culturally unrelated to the Bushmen, who assimilated them before the migration of the Bantu into the south began (Snyman I974, 29-30; Traill I978, I46; I985; Van Vuuren 20I6).

\section{Multiple languages in contact situations}

The San and Khoikhoi spoke many different languages and dialects; some 30 Bushman languages had been identified and recorded since the early I850s (Bleek I956, iii-iv). Most of the speakers of these ancient indigenous languages have vanished and their spoken languages have become extinct. This process occurred more often by acculturation and assimilation of smaller groups of speakers than merely by being "forgotten" in historical times (Boden 20II; Van Vuuren 20I6, 20I-227).

Many adopted words and names illustrate processes of inter-linguistic contact between various languages, in terminology used for traditional customs and in names of domesticated and wild animals. Compare the word for "goat" in the !Kung and Hie languages as in the variant allonyms birilburi adapted to pudi in the Tswana toponym Pudimoe, and in Nguni where buri/pudi appears as mbuzi. The names for the savanna baboon, the chacma, are inter alia // $k a$ and / $k a \_/ k a$ from the / Nu//en Bushman language (Bleek I956, 305, 695), recorded as Khoikhoi choa kamma in 1705 by Valentyn (Nienaber I963, 202), and adapted to cwama in the Xhosa place name Incwama.

\section{The nature of multilingual place names}

Multilingual names require a theoretical approach towards understanding the influence that the mix of typologically non-related, grammatically very differing languages had on the naming of features. The impact on the usage of names as designators, or the inter-changeability of place names on a linguistic and onomastic level through borrowing, adaptation, translation, hybridization, folk-etymology and other activities, is demonstrated in further examples discussed later.

The main notion is that multilingual place names often exhibit fossilized components, some only as remnants of words and phrases from the Bushman and Khoikhoi languages. This article focuses on retracing these names that have become as faint as the footsteps of the ancestral speakers, and how the threads of their vanishing languages and words are barely recognizable in the place names today. In this type of paleo-linguistic research the inter-layered, multilingual context has become the palette of this study. That traces of their words are recognized in many place names, and may be re-assessed within this onomastic context, is re-affirmed through ongoing comparative research. 


\section{Method and data collection}

The naming motives, etymologies and adaptations of names can be retraced by applying various onomastic and linguistic verification methods. These include the "sound-meaning” technique (Heine and Honken 20IO, II), i.e. considering phonological and semantic aspects of a name; in researching ancient Bushman words (paleo-onomastics); looking at toponymic cluster formations, i.e. finding more than one name in a region related either by translation, hybridization or other adaptations; by deciphering cognates ${ }^{\mathrm{I}}$ or equivalent name pairs or allonyms, and by recognizing that they appear in different written forms. This may be achieved by comparing the phonological and orthographic renderings of the names diachronically. The approach is multi-disciplinary, looking at the context of socio-linguistic activities including cultural traditions, possible code-switching during translation in bilingual contexts as defined by Blom and Gumperz (I972) and Hymes (I974), also noting possible misinterpretations, borrowings, folk-etymological and grammatical adaptations.

The data was collected from fieldwork and a variety of digital sources, from archival documents, diaries and travel journals, as well as onomastic research publications. From the literature on Bushman and Khoikhoi names, a picture emerged of how these naming actions were linked to the specific inter-linguistic processes, including derivations and adaptation of onomatopoeic creations and equivalents or cognate forms probably derived from more than one ancestral proto-language.

Analysis of the compounded names and comparison of the etymological origins or semantic concepts surfacing from the underlying sub-structures, revealed various evolutionary onymic formatives (early naming elements) in these place names, thereby displaying their multilingual layers.

The research on these place names from different source languages demonstrates both acculturation and inter-linguistic processes impacting on the onomastic activities. It provides new insights into the oldest layers of names in a varied, interwoven toponymicon, i.e. place names that constitute a shared heritage.

\section{Paleo-onomastic research requirements}

Paleo-onomastic research into multilingual place names requires awareness of language specific adaptations, e.g. phonological and grammatical additions, folk-etymological adaptation, translations and other naming actions. Multilingual indigenous toponyms are complex in their phonological and morphological structuring, and therefore difficult to interpret (Möller 20I4, I4O). They can be explained by tracing comparable equivalent words or root elements of proto-languages; by deciphering the orthographic changes they underwent, and analyzing the components in composite structures. In so doing, it is possible to recognize original Bushman words, added Khoikhoi and Bantu grammatical indicators such as locatives, plurals, diminutives, gender markers, e.g. $-b,-p,-s$ in Khoikhoi (Nienaber and Raper I977, 57); prefixes such as $\mathrm{Di}^{-}, \mathrm{Ga}-\mathrm{K} \mathrm{wa}^{-}, \mathrm{Ma-}, \mathrm{Mo-}$, $\mathrm{Se}$-, or suffixes such as -ana, -ini in Bantu languages.

Another objective is to find similar words that may be indicative of items functioning as borrowed or loan words in other languages, or the more obvious translation processes where the translated name provides the meaning, even if only as partially translated or 
hybridized construct; often resulting in tautological forms. A few examples discussed later contain references to adapted and translated phrases and metaphoric expressions as well as folk-etymological adaptations that have become part of the colloquial usage in other languages.

\section{Names as evidence of the "absent presence"2 of the "First Namers"}

Most of the Bushman and Khoikhoi languages, though extinct or moribund, ${ }^{3}$ still echo in the sounds of names bestowed on geographical features, i.e. those places where the speakers roamed. Where the names were recorded, the distinct sounds of these languages, e.g. clicks or suction sounds, phonemic cluster formations and root words, have to some extent been retained, although most went through phonological abrasions and later orthographical modifications (Raper 20II, I-I8; 20I2, 3I-34, I6I-I62). ${ }^{4}$

To enable the verification of the names as deriving from original Bushman and Khoikhoi concepts, naming motives and patterns, they need to be validated through a multilingual approach, since many have been corrupted over the years to almost unrecognizable forms. This requires attention to the phonological and semantic aspects as noted earlier, and remaining aware of the variations created by different speakers, the eventual semantically differing forms emanating from these adjustments, translations in bilingual situations and those relating to possible code-switching, inter alia as with hlonipa or avoidance names. Ultimately, this implies re-evaluation in the analysis of their etymologies.

The former much wider distribution of the Bushman speakers (Bleek 1927; Traill 2007) can, apart from paleontological and archaeological evidence (Deacon and Deacon I999), be retraced in the names they allocated to features such as mountains, caves, rivers, fountains, marshes, grasslands and plains, and their ethnonyms relating to such features.

From their oral traditions a naming system evolved that reflects a precise and efficient orientating system by which geographical features and other entities were identified. It demonstrated certain hunter-gatherer actions, e.g. rituals as observance of respect towards certain animals after the hunt, or to avoid contact with them, for instance with the lion (Bleek I956, 256, 477, 597, 694); in food gathering and observation of, and being observed by other people living in the area. One such example is the multilingual river name Senwabathwana, named by Sotho and Nguni speakers and explained as the stream from which "the San people drank water" (SAGNC 2004-20I2). The adapted component bathwana referred to the Bushmen living in the north-eastern parts of southern Africa, being called Batwa (Bleek I929, I; I956, ii-iii); Bathwana by Swazi-speakers (Möller 20I4, I36).

\section{Categories of multilingual onomastic processes exemplified}

The examples of multilingual place names illustrating these creative onomastic processes often demonstrate more than one linguistic aspect of adaptation in the naming process. For this reason certain categories may overlap.

\section{Derivations and adaptations}

These may take various forms as in the cases of sound imitations or onomatopoeia, i.e. names derived from the vocalization(s) or other sounds made by animals being first 
allocated as common names then place names. One name for the lion in the /Xam and Hie languages is hou: $m$, an onomatopoeic designation used as toponymic reference to the Houms River; another, from the $/ \mathrm{Nu} / /$ en and !O!kung languages, is xam or gam "lion" (Bleek I929, 54; I956, 732). In Afrikaans a lion is "leeu", and the Khoikhoi toponym Gamka was translated as Leeuwenrivier, "lion river" (Brink in Mossop I947, 30-3I). The town name Leeu-Gamka was derived from the two names forming a tautology, "lion-lion river".

The name of the "honking" hippopotamus which in some Bushman languages is kubu and nguvu, was adapted to imvubu in Zulu and applied in the river name Umzimvubu. In Venda it appears in the toponym Levubu. In this instance the interchangeability of $b$ and $v$ is evident.

The ostrich is called mptsu in the Auen language (Bleek 1956, I38), and $m p t \mid u, t j w e$, in other Bushman languages (Bleek I956, 740), apparently named after the sound made by the hen and chickens. This name was adapted into the Tswana language as imple and in Sotho as mptšhe, and allocated to place names such as Dimpšhe, "(pan of) many ostriches", and Metsimpšhe, "fountain of the ostriches". These names, subsequently translated into Afrikaans, became Volstruispan and Volstruisfontein (Möller 20I4, I28).

\section{Phonologic, orthographic and folk-etymological adaptations}

Onymic formatives derived from equivalent or cognate words, either from a common ancestral root word or by borrowing from another, unrelated language, are not easy to identify or interpret. One such example, the Bushman name for the hyena, //goaan from the /Xam language (Bleek 1956, 532), appears in adapted form in several Nama / Afrikaans hybrid place names such as Guaapvlakte ("Guaap Flats”) and Gwaapseberg ("Gwaap Mountain"), and is found in the name Wolf River (Nienaber and Raper I980, 37I; Raper, Möller, and Theodorus du Plessis 20I4, I69, 547). These names indicate the variations in phonologic representation, spelling and translation.

Similarly, the mountain name IDlangampisi underwent multilingual toponymic metamorphoses, appearing as Hlangampisi or iDlangampisi. It is another example of reinterpretation of an obsolete generic term from Bushman leading to an apparent tautology. Several versions of the origin and meaning of the name have been encountered, namely "gathering place of the hyena", "feeding place of the hyena", the "place of the raw meat eaters" i.e. "scavengers". Since it is the name of a prominent mountain, it may be assumed that it had already been named long before other language speakers arrived, translating and adapting it because of its "unknown" generic and loss of meaning. Analysis of the component dlang shows that it was either adapted from a proto-type generic !goa, "mountain" (Bleek I956, 737), thus "mountain of the hyena", or that the word //goaan already stood for "hyena", in which case it was correctly translated, with the Zulu word mpisi "hyena" added, that resulted in the tautology "hyena+hyena". In the toponym it was grammatically adapted by Nguni prefixes which led to different interpretations. Phonologic adaptations occurred by softening of the clicks ! and // to $d l$ or $h l$ and eliding the $o a$ of the phonemic cluster oaan to ang (since juxta-positioning of two vowels does not occur in Nguni). The Afrikaans-speakers heard the name Hlangampisi, reinterpreted it phonologically and with folk-etymological adaptation to a name understandable in their own language, Slangapiesberg, which means "snake monkeys' mountain". 


\section{Loan words and folk-etymology}

Loan words often appear as folk-etymological adaptations, e.g. the word !nõ:na from //N!ke for a certain "type of owl", adapted into Afrikaans as "nonnetjiesuil", a reference to the barn owl. The region name Nonikam was translated into German Eulenruh, i.e. literally "owl's rest", and allocated as farm name. It derived from an ancient Bushman designation where !nõna+kam meant "owls' roosting place” (Möller 20I7).

The place name INqu refers to the "Wildebeest River" and derives from the Bushman and Khoikhoi words (Bleek I956, 77I) gnu, !gnu; !nu: > (i)nqu in Xhosa (Raper, Möller, and Theodorus du Plessis 20I4, 543). The Xhosa toponym Cocong is an adaptation derived from the original /Xam name for this animal as !au/ko (Bleek I929, 92), and the adapted Nguni inkonkoni and southern Sotho khokong all relate to Cocong with the -ng a locative marker (Möller 20I7).

The name Mosukudutzi, translated as Koedoespruit "stream of the kudu", derives from old Cape dialectal words coedoes, cuhduh, !cudou, cudau (Nienaber 1963, 344), an onomatopoeic name imitating the grunting or barking sound this kudu antelope (Strepsiceros capensis) makes when startled.

\section{Translation of multilingual indigenous names}

Translation of names may appear as either full or partial translation, as hybridizations, tautology and reduplicated forms. The hybridized names or names of a dual nature involve various elements, both structural and semantic, from two or more languages appearing as composite names.

Full translations occur profusely in the region, e.g. as found in Chammadaos $>$ Afrikaans Leeupoort "lion path"; Paayzynpan is an adaptation from //gailai and gwei/gweiten, meaning "tortoise", relating to the nearby Skilpadpan, "tortoise pan", presenting another toponymic cluster translation (Möller 20I4, I29-I30; Raper, Möller, and Theodorus du Plessis 2014, 95).

Another example is the name of a gorge in the Western Cape, Theewaterskloof, also written as Teewaterskloof. The first part of the name is indicated as "very old and probably from Khoisan" origin, but the meaning remained "not known" (SAGNC 2004-20I2). If the first two components of the name are compared with ancient Bushman words, the relation between the word thee or tee, and the second component water, is recognized. The first component thee means "water", comparable to the /Xam and Hadza words $\neq e:,-/ i$ and (a)ti (pronounced as tee or thee), a term used widely as designation for "flowing water", often written differently in Bushman languages (Bleek 1956, 292, 769). The pronunciation of the $\neq$ (the alveolar-palatal click) and the / (the dental click), sounding like a $t$, with the long vowel $e$ : produced thee or tee in writing. This component $\neq e$ : was correctly translated into Afrikaans and English as "water" (same semantic content), giving the explanation for this "unknown" name. By analyzing the components as tautology in this hybridized name, the etymology of the toponym could be verified, thus thee ("flowing water") became Theewaterskloof, "flowing water ravine".

The toponym Graatjiegat-se-bult, meaning the "hillock of the meerkats' holes", contains the Afrikaans loan word "graatjie", derived from Bushman xaragi, the name for the thin-tailed meerkat (Suricata suricatta). 


\section{Imagery, metaphors and descriptive names}

A few examples contain references to imagery, metaphoric expressions and translated phrases that have become part of the colloquial usage in other languages.

The chacma baboon was metaphorically described by the Bushmen and Khoikhoi as /nera-b, "he who measures his strides", from a verb /nera "to measure" (Kroenlein I889, 252). This name for the baboon appears in a few toponyms in Namibia and the Cape Province. Nerahoas was translated as Bobbejaanskrans, meaning "baboons' cliff", from Khoikhoi /nera "baboon", //hoas, "cliff". Neranaisib refers to a rock overhang in Namibia explained as "baboon's slope" (also explained by locals as "baboons birth place"), composed of nera+nai from /Xam $\neq k h a \hat{\imath}$ "slope", with a Nama generic or feature identifier -sib added.

The black rhinoceros, described as the one "stamping with hooves", known to present with this action when threatened or scared, is called !nabas in Auen and Kung languages. This word occurs in the place names Nababeep, Nabasberg, "rhino mountain". The rhinoceroses have poor eyesight and this characteristic gave rise to the name of the white rhino in Khoikhoi as mogoe koep, comparable to Tswana and Sotho mogohu, the "nearsighted one". The name derives from the verb mu: "to see", synonymous with moe from Naron and moo from the Hie language (Bleek I956, I39). The word mu or moe in its broader sense refers to "sight", "eyesight” (Bleek I956, 768). The word for "near", "to be near", and the concept of "close by", is given as !guu, / $k u$ in the Hie language and / ku: in Naron (Bleek I929, 60; I956, 26, 710). This name of the great herbivore is eternalized in the place name Mogoekoep translated as Renosterkop, "rhino hill” (Möller 20I7).

The elephant is described as the "trumpeter" and "trampler". Its name in Bushman is xchua, tlowa, found in the toponym Thuata, Tuhata translated into Dutch as early as I724 as Oliphants Revier. Another toponym, Kwacao, derives from the forms written as /xwa:, kwa, koa. A Hadza Bushman word for "elephant" is bel/k"aau (Bleek I956, I6, 7I4), adapted to tlou in Tswana and Sotho as in the toponym Tlhaka le Tlou, "reeds of the elephant" in the Northern Cape (Raper, Möller, and Theodorus du Plessis 20I4, 498-499). In Nguni languages, indlovu is said to be a derivation from the Ur-Bantu -үoү $\hat{u}$ for "elephant", encountered in the place name Umgungundlovu.

\section{Traditional oral sources of names}

Naming from traditional oral sources often concurs with onomatopoeia, or where components contain phrases or references to song and dance and other rituals, often adapted as folk-etymology, e.g. the Northern Sotho place name Giyani, which is said to mean "place of dancing" (Raper, Möller, and Theodorus du Plessis 20I4, I53). From the Auen verb -/gi: "to dance" (Bleek I929, 32), the associated phrase "to sing and dance together" is derived, cognate with the words !xai, t txai in the Naron language, and the related -gita in Nguni.

In the toponym Giribes, “jackal's fountain” (Nienaber and Raper I977, 4I8), a link may be found in the description of the jackal's vocalizations and its names, as in Nama /giri-b and /geira- $b$; the cognate Bushman designations for the silver fox, Vulpes chama, as /giri, and //ai from the !O!kun language, and for the black-backed jackal/gi:ri:mi: in the !Kung language (Bleek 1956, 279), also found as as /giri, /kire: or /geriba in Naron 
(Bleek I929, 49-50), and /kire:- $p$ in Koranna (Maingard I932, 3I3), because their young make a distinct giri-giri-giri sound when distressed. These names concur with the observations made of the jackal's behavior, i.e. from the root verb /gai "to yowl, yelp together", seen as metaphorical concept of "singing" (Kroenlein I889, 240); or "crying" (Bleek I929, 3I); derived from the word $k^{\prime}$ ai in the Auen language, $k$ "xai from Naron and - $\neq$ gei from Nama.

The explanation of the jackal's onomatopoeic name to a metaphoric phrase, to a toponymic formative, was made from observations by local Khoikhoi speakers (Schultze I907, 283, quoted in Nienaber 1963, 318).

In oral traditions folk-etymological adaptations regularly occur in place names, compare for instance Toorberg, the name of a mountain in the Colesberg district, Western Cape. Many different spelling forms and various explanations were encountered, e.g. as Toorberg, which appears to derive from the Afrikaans words toor, "to bewitch" +berg, "mountain" (Raper, Möller, and Theodorus du Plessis 20I4, 500). Yet, its real name does not mean "magic or bewitching mountain", nor was the older, alternative Dutch spelling Toornberg correct, "toorn" meaning "wrath" that led to the interpretation of it as "Wrath Mountain". These variations have been misleading. The first component is a Bushman word of which the basic naming formative thoo, to: $a, t$ o means "mercy" (Bleek 1956, 200, 735), thus Toorberg should be read as "Mountain of Mercy". The translated name in Afrikaans is indeed Genadeberg (Skead I973, 226), genade meaning "mercy". In this form it is clear how the etymology may be justified, i.e. said to refer to an incident, an act of either mercy or consolation, having occurred at the mountain. Embedded in this interpretation, stemming from the oral traditions of the region, is a reference to the medicine man or shaman, someone who could mediate between people, or a person and his token animal, for his spiritual well-being (Deacon and Deacon I999, I68-I72; Van Vuuren 20I6). This mediation from a consulting shaman in all kinds of situations was seen as a "merciful" act and gave rise to the name of the mountain where these acts were performed.

Similarly, the name Hlonasedimong, referring to a water feature in the Limpopo province, was translated as Towerfontein, "magic fountain". This is another name with components from various languages, but its origin verifiable from established Bushman oral tradition of the Masele and their reference to the feature. These people were called Vaalpense, "grey bellies", the acculturated San people living in the region to the north and west of the Waterberg in this province (Van der Ryst 2003, 42-52). It was recorded on earlier maps as Thlonasedimong with the $T$ indicative of a click sound as retained in words from Bushman and Khoikhoi languages. The name, derived from the words $t$ fo $a$, t oma for "magic" in the Auen, //Xegwi and Naron languages, also refers to a magician, he who is able to perform "disappearing acts", hlona relating to the term "blonipa" in the Nguni languages, i.e. "to conceal or hide away", "to make something disappear", further amplified as traditional act "to avoid" or "showing respect". Underlying the name are the observations of the local people "of the disappearance of the water in winter, and the sudden reappearance after good rains, like magic” (Möller 20I4, I33). By translating the name, either by the bilingual Masele, or the original Bushmen themselves, otherwise by Afrikaans-speaking people, this natural phenomenon and an accompanying tradition were immortalized in the place name. 


\section{Conclusion}

The Bushman and Khoikhoi common names for animals, geographical features and other entities have resulted in place names so closely embedded in the natural world where these people lived, that evidence of them as namers, and of their languages, abound in the multilingual toponymic landscape of the region.

These names indicate onymic and lexemic exchange having taken place, preserving language elements and structures that have survived to this day. They are being officially recognized and in many instances re-instated, complying with the stipulations of the Constitution of South Africa to promote and protect indigenous minority languages.

As the examples illustrate, the often opaque, "unknown" place names, or difficult to analyze components in such names, are in fact fossilized remnants of earlier naming actions by the "First Namers" in the region, namely the Bushmen and Khoikhoi. The processes of acculturation that began when the Bantu and the Europeans migrated into the region, resulted in many place names being modified and translated. The names for geographical features and other entities demonstrate these processes of linguistic intermingling, the development of a bilingual and multilingual context, and the multi-layered legacy of the toponyms they left behind.

Research into the indigenous Late Stone Age and Iron Age naming activities in southern Africa remains daunting because the languages are mostly extinct. The key challenge lies in recognizing and comparing them; utilizing reliable information accessed mainly from the translations of words and names from some of the extant, as well as extinct languages or dialects. It is acknowledged that the origins of most indigenous place names in this southern part of the continent developed from the keen observations made by Bushmen hunter-gatherers, Khoikhoi herders and Bantu agro-pastoralists. These names highlight their acute conceptual awareness, showing an imagery of exceptional beauty and an aptitude of linguistic expression in their naming activities and in the names they bestowed.

In studying the languages, names, myths, legends and folktales of the indigenous peoples of the region, and their perceptions about the origins of man and animals, the vibrant expressiveness of their mythical and spiritual experiences on all levels of their social and physical existence, comes to light. The continued research on Bushman and Khoikhoi names confirms their role as originators of the toponyms, and affirms their presence as part of this shared multilingual onomastic heritage.

\section{Notes}

I. Cognate word: related in a manner that involves borrowing rather than descent from or as well as descent from an ancestral language" (Gove I96I, 440).

2. Reference to a quote by Van Vuuren (20I6, I28): “... the in absentia presence of the exterminated /Xam”.

3. A classification of Khoikhoi and Bushman existing, extinct or moribund languages and their dialects appears in "Khoisan (Khoesaan) languages in Africa", <https:// en.wikipedia.org/w/index.php?title $=$ Khoisan languages\&oldid $=717392325>($ Accessed November 20, 20I6).
4. The distinguishing clicks used in the Bushman and Khoikhoi languages are indicated by phonetic symbols, namely: the dental click /, formed by pressing the tongue against the back of the teeth and withdrawing it; the alveolar or palatal $\neq$, by withdrawing the tongue from the alveolus; the lateral click //, by withdrawing the side of the tongue from one side of the back molars; the cerebral !, by withdrawing the tip of the tongue from the roof of the mouth; and the lip click $\Theta$, by making the sound of a kiss (Bleek I929, I3; Traill I978, I37-I38). Other 
phonetic symbols used to represent the pronunciation of words are: the colon : indicating a long vowel; the tilde $\sim$ for nasalization; the single quote' for a glottal closure; the double quote" for a strong glottal closure (Raper 20I2, I4-22).

\section{Disclosure statement}

No potential conflict of interest was reported by the author.

\section{Bibliography}

Bleek, Dorothea F. 1927. "The Distribution of Bushman Languages in South Africa." In Festschrift Meinhof-Sprachwissenschaftliche und andere Studien, edited by Franz Boas et al., 55-64. Hamburg: L. Friedrichsen \& Co.

Bleek, Dorothea F. 1929. Comparative Vocabularies of Bushman Languages. Cambridge: University Press.

Bleek, Dorothea F. 1956. A Bushman Dictionary. New Haven, CT: American Oriental Society.

Boden, G. 20II. "The Documentation of Place Names in an Endangered Language Environment: A Case Study of the !Xoon in Southern Omaheke, Namibia." Anthropological Linguistics 53 (I): 34-76.

Blom, Jan-Petter, and John J. Gumperz. I972. "Social Meaning in Linguistic Structures: Code-switching in Norway." In Directions in Sociolinguistics: The Ethnography of Communication, edited by John J. Gumperz and Dell Hymes, 409-434. New York: Holt, Rinehart and Winston. Inc.

Deacon, H. J., and Janette Deacon. 1999. Human Beginnings in South Africa: Uncovering the Secrets of the Stone Age. Cape Town: David Phillips.

Gove, Philip Babcock, ed. I96r. Webster's Third New International Dictionary of the English Language. Springfield, MA: G \& C Merriam Co.

Heine, Bernd, and Henry Honken. 20I0. "The Kx’a Family: a New Khoisan Genealogy.” Journal of Asian and African Studies 79: 5-36.

Hymes, Dell. 1974. Foundations on Socio-linguistics: An Ethnographic Approach. Philadelphia, PA: University of Pennsylvania.

Kroenlein, J. G. I889. Wortschatz der Khoi-Khoin. Berlin: Deutsche Kolonialgesellschaft.

Maingard, L. F. I932. "Korana Names of Animals and Plants." Collected by Dr. Lucy Lloyd. Bantu Studies 6 (4): $3 \mathrm{II}-32 \mathrm{O}$.

Möller, L. A. 20I4. "Some Thoughts on Revised and Replaced Toponyms in South Africa." Nomina Africana 28 (I): IO7-I42.

Möller, L. A. 2017. Of the Same Breath: Indigenous Animal and Place Names. Bloemfontein: SUN MeDIA Press.

Mossop, E. E., ed. 1947. The Journal of Carel Frederik Brink of the Journey into Great Namaqualand (I76I-2) made by Captain Hendrik Hop and The Journal of the Journey of Ensign Johannes Tobias Rhenius (I724). Cape Town: Van Riebeeck Society XXVIII.

Nienaber, G. S. 1963. Hottentots. Pretoria: Van Schaik.

Nienaber, G. S., and P. E. Raper. 1977. Toponymica Hottentotica A. Pretoria: Human Sciences Research Council. Nienaber, G. S., and P. E. Raper. I980. Toponymica Hottentotica B. Pretoria: Human Sciences Research Council. Raper, Peter E. 20II. "Interpretations and Translations of Bushman (San) Place-Names.” Acta Varia 2: I-I9.

Raper, Peter E. 20I2. "The Bushman (San) Influence on Zulu Place Names.” Acta Academica Supplementum 2: I-I86.

Raper, Peter E., Lucie A. Möller, and L. Theodorus du Plessis. 20I4. Dictionary of Southern Africa Place Names. Cape Town/Johannesburg: Jonathan Ball Publishers.

Skead, C. J. I973. "Zoo-Historical Gazetteer." Annals of the Cape Provincial Museums Io (i-v): I-259.

Snyman, J. W. 1974. "The Bushman and Hottentot Languages of Southern Africa." Limi 2 (2): 28-44.

South African Geographical Names Council (SAGNC). 2004-I2. Schedules, Database. Pretoria: Department of Arts and Culture.

Traill, Anthony. 1978. The Languages of the Bushmen. In The Bushmen, edited by P. V. Tobias, I37-I47. Cape Town: Human and Rousseau.

Traill, Anthony. 1985. Phonetic and Phonological Studies of !Xóõ Bushman. Hamburg: Helmut Buske.

Traill, Anthony. 2007. “!Khwa-Ka Hhouiten Hhouiten, 'The Rush of the Storm': The Linguistic Death of /Xam.” In Claim to the Country. The Archive of Wilhelm Bleek and Lucy Lloyd, edited by Pippa Skotnes, I30-I 47. Auckland Park: Jacana Media.

Van der Ryst, Maria. 2003. "The So-Called Vaalpense or Masele of the Waterberg: The Origins and Emergence of A Subordinate Class of Mixed Descent.” Anthropology Southern Africa 26 (I/2): 42-52. 
Van Vuuren, H. 2016. A Necklace of Springbok Ears. / Xam orality and South African literature. Stellenbosch: SUN MeDIA Press.

\section{Notes on contributor}

Lucie A. Möller, Research Fellow, Unit for Language Facilitation and Empowerment, University of the Free State, Bloemfontein, South Africa; member of the American Names Society and honorary member of the Names Society of Southern Africa. Her research focuses on southern African toponymy, ethnonymy and animal names.

Correspondence to: Lucie Möller, I 998 Dunwoodie Avenue, Waverley, or 86, Pretoria, South Africa. Email: lamoller@absamail.co.za; Tel: +27-I2-332I5I8, o8I3009730 